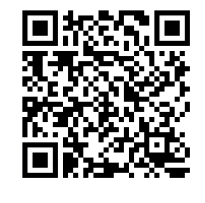

Keywords:

Toxicity

Papermaking waste sludge

Petrochemical ash

Metakaolin

Heavy metals

Historic:

Received 02/08/2018

Accepted 03/12/2018

Correspondence:

f_mkazemi@sbu.ac.ir

\title{
PAPERMAKING WASTE SLUDGE FIBER-CEMENT COMPOSITE PANEL: STABILIZATION AND SOLIDIFICATION OF HIGH FE AND TI CONTENT- PETROCHEMICAL ASH
}

MOHAMMADKAZEMI, F. Papermaking waste sludge fiber-cement composite panel: stabilization and solidification of high Fe and Ti content-petrochemical ash. CERNE, v. 24, n. 4, p. 303-3II, 20 I8.

\section{HIGHLIGHTS}

Effect of papermaking waste sludge, petrochemical ash, and metakaolin was investigated.

Toxicity, MOR, MOE, FT, IB, WA, density, and XRD patterns were compared.

Successful stabilization and solidification of heavy metals occurred.

It is possible to reuse PWS and ash in FCCs with reduced environmental pollution

\section{ABSTRACT}

In this study, the effect of papermaking waste sludge (PWS), petrochemical ash, and metakaolin (MK) replacement with portland cement in the manufacturing of fiber-cement composite (FCC) was investigated. Moreover, the toxicity of materials and FCC was evaluated. Modulus of rupture (MOR), (MOE), fracture toughness (FT), internal bonding strength (IB), water absorption after 24h immersion in water (WA24), and density of FCCs were measured. X-ray diffraction patterns were also obtained. According to the main results, Composites produced with 6\% PWS content showed superior mechanical properties. Higher contents of PWS resulted in the reduction in fiber-matrix interfacial adhesion, increasing void contents, and hence lower strength properties. Replacing petrochemical ash and MK up to I0\% provided optimum combinations and lightweight composites. In addition, X-ray diffraction patterns confirmed pozzolanic reactions of materials. Toxicity investigation showed that concentration of heavy metals in FCC leachate were reduced compared with ash. Pozzolanic reaction of materials had positive influence on solidification and stabilization of heavy metals. In conclusion, FCCs with the highest pozzolanic activity, were considered as the optimum combination. Moreover, successful stabilization and solidification of heavy metals occurred. Therefore, not only PWS and petrochemical ash can be reused in FCC manufacturing, but they also in turn reduced environmental pollution. 


\section{INTRODUCTION}

During the last decade, global demand for cheap housing has been increasing especially in both developed and developing countries. It was shown that FCCs possess lower density, superior fracture toughness, ductility, flexural capacity, and crack resistance as compared to non-fibrous cement composites. They can be applied as a material for ceiling, roofing, internal/external wall, and facade (Khorami; Ganjian, 20 II; Mohr et al., 2005). Considering the lack of wood resources and banning asbestos fibers, there is a great interest to use agricultural wastes such as bagasse fibers, recycledfibers; and differentindustrial wastes in manufacturing FCCs. Since construction consumes large amounts of materials, the utilization of such wastes in manufacturing cement composite offers an appealing alternative to their disposal (Protásio et al., 2017; Mohammadkazemi et al., 20 I5; Abdel-Kader; Darweesh, 20 I0).

Nowadays, the industrial waste generation has increased considerably worldwide. In this regard, incineration was introduced as an alternative for reducing the volume of the wastes, which in turn, produce ash as another waste and has a destructive effect on the environment. One of the most critical environmental issues is industrial waste management which requires sustainable strategies. The most suitable and economic option for reducing ash and minimizing its hazardous effects on the environment is to utilize it in the manufacture of construction and building materials (Rajor et al., 20 I2; JIDRADA et al., 20 I6). In this regard, stabilization/Solidification (S/S) is typically a process that involves the mixing of a waste material with a binder to reduce the contaminant leachability by both physical and chemical methods and to convert the hazardous waste into an environmentally acceptable waste form for land disposal or construction use. Portland cement is one of the most commonly used binders for $\mathrm{S} / \mathrm{S}$ because of its availability and low cost (Spence; Shi, 2004). Fly ash and bottom ash are two important types of solid industrial wastes. In recent years, it is reported that many waste materials/by-products have been used in controlled low strength materials such as fly ash, bottom ash, foundry sand, paper pulp, kiln dust, crumb rubber, glass and so on (Qian et al., 20I5). Butler et al. used type I Portland cement and type $\mathrm{N}$ sodium silicate solution to solidify $\mathrm{Cd}, \mathrm{Pb}$, and phenols. The analyses have been found to support the leaching and mechanical property test results (Butler et al., 1988). In another study, it was shown that bottom and fly ash produced from incinerated hospital waste can be used for the production of concrete and bricks (Tay, 1987). Genazzini et al. evaluated the feasibility of including hospital waste ashes in cementbased materials. According to their study, suitable strength levels were reached (Genazzini et al., 2003; Genazzini et al., 2003; 2005).

Among different industries, papermaking factories produce high amounts of solid wastes which need high cost for land disposal and put a high pressure on the environment (Monte et al., 2008). The production of dry industrial sludge is approximately $4.3 \%$ of the final products, reaching to $20-$ $40 \%$ in the case of recycled paper mills (Ochoa de Alde Jesus, 2008). Moreover, the "Sustainability Report 20I5" filed by the Domtar Corporation reported that about $141 \mathrm{kt}$ of solid wastes were landfilled in 2014 (Wu et al., 2016). These sludges are commonly dried, deposited in the landfill, spread, or incinerated to reduce their volume and to recover part of energy (Lou et al., 20 I I). New strategies aim to prevent or reduce negative effects of these landfills on the environment. It was reported that papermaking waste sludge (PWS) containing a high content of inorganic solid materials as well as chemically modified natural fibers (organic components) can be used in the production of construction and building materials (Andreola et al., 2005; Chang et al., 2010; Chung, Naik, 2005; Modolo et al., $201 \mathrm{I}$; Yan et al., 20 I I). It was shown that addition of 5- I 5\% of sludge improves both the final product and the process. Its fiber content increases the porosity of the composite; therefore, it enables producing lightweight constructions (Monte et al., 2008; Furlani et al., 20 I I). Yan et al. reported that including up to $20 \%$ of sludge into mortar improves its mechanical properties (Yan et al., 201 I). Using PWS in the production of fiber-cement sheets showed environmental and economic benefits (Modolo et al., 20 I I).

Metakaolin (MK) is a pozzolanic and thermally activated alumino-silicate material obtained by the calcination of kaolinitic clay at a temperature of $500-800^{\circ} \mathrm{C}$. The raw material input in the manufacture of $\mathrm{MK}\left(\mathrm{Al}_{2} \mathrm{Si}_{2} \mathrm{O}_{7}\right)$ is kaolin. The positive influence of MK on mechanical properties, including compressive, tensile, and bending strengths of cement-based materials was confirmed by previous studies (Menhosh et al., 2016; Siddique; Klaus, 2009). MK demonstrated excellent pozzolanic characteristics due to the amorphous structure and high specific surface (Sabir et al., 200 I; Love et al., 2007; Castellanos et al., 20 I 5). Pozzolanic reactions of MK change the microstructure of cementitious composites and chemistry of hydration products by utilizing released calcium hydroxide $(\mathrm{CH})$ and production of extra calcium silicate hydrate $(\mathrm{CSH})$ gel resulting in an improved strength and durability (Shekarchi et al., 20 I0).

Despite the requirements for the strength of composite manufactured with industrial ash, toxicity and health issues should be considered. Toxic elutes that include hazardous wastes from poorly stabilized/Solidified materials 
could severely contaminate the groundwater, surface waters and the environment (Spence; Shi, 2004). According to the importance of the topic, the aim of the present study is oriented to investigate the possibility of using a high Fe and Ti content petrochemical ash (bottom ash) and PWS as industrial wastes in the manufacture of FCCs. The effect of MK on physical and mechanical properties of composites was also assessed. Indeed, the toxicity of materials and manufactured FCC was evaluated.

\section{MATERIAL AND METHODS}

Material

Bleached bagasse pulp fibers were provided from Pars papermaking mill, Khuzestan, Iran; 2\%wt. pulp fibers were used in fiber-cement composite manufacturing. Length and diameter of fibers were $1.26 \mathrm{~mm}$, and 26.97 $\mu \mathrm{m}$, respectively. Also, PWS was provided from a papermaking mill, Iran. Total organic components, length, and width of PWS were $50.38 \%, 1.63 \mathrm{~mm}$, and 24 $\mu \mathrm{m}$, respectively. Figure I represents SEM micrographs of PWS used in FCC manufacturing $(a, b)$ as well as images of materials (c). A high Fe and Ti content bottom ash, provided from a petrochemical plant in Khuzestan, Iran, was prepared from incineration of petrochemical wastewater sludge at $600^{\circ} \mathrm{C}$. All materials were ground by a rotary mill with a feed size of $0.5 \mathrm{~mm}$. The $M K$ used was a commercially available natural pozzolan imported from India. Type II Portland cement (PC) was used to manufacture FCCs. Poly-carboxylate based superplasticizer was also used $0.5 \%$ by dry weight of cement to achieve the desired workability.

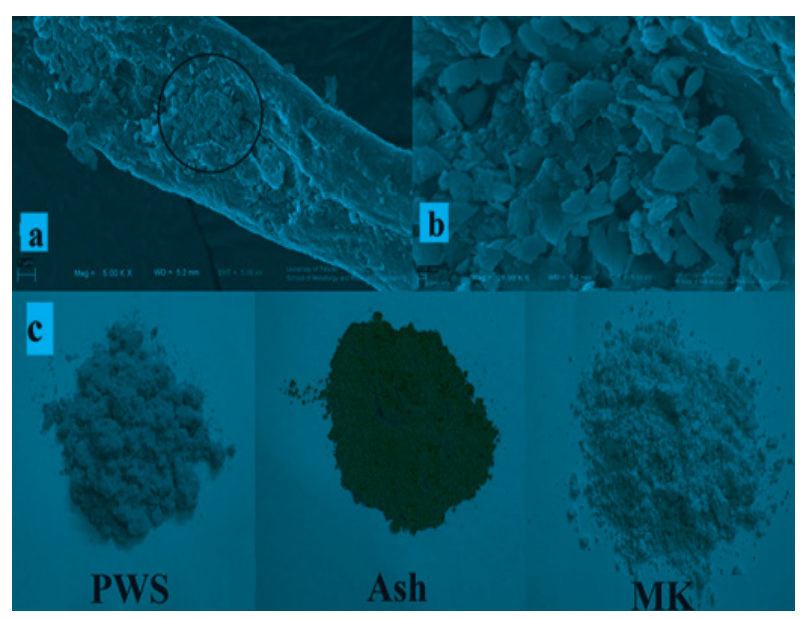

FIGURE I Scanning electron microscopy micrographs of papermaking waste sludge (PWS) (a, and b: higher magnification), images of PWS, ash, and Metakaolin (c).
The chemical composition of PC, ash, PWS, and MK obtained from XRF analysis are presented in Table I. The high percentage of some metals such as $\mathrm{Fe}_{2} \mathrm{O}_{3}$ or $\mathrm{TiO}_{2}$ may be due to the use of metal chloride in the process of coagulation and flocculation in the drainage tanks, as well as washed metals from the reservoirs, distillation columns and metal pipes, which appeared in the ash after combustion of the sludge.

TABLE I Chemical composition of portland cement, papermaking waste sludge, ash, and Metakaolin.

\begin{tabular}{ccccc}
\hline Chemical & \multicolumn{4}{c}{ Concentration (w/w \%) } \\
\cline { 2 - 5 } composition & $\mathrm{PC}$ & $\mathrm{PWS}$ & Ash & $\mathrm{MK}$ \\
\hline $\mathrm{Na}_{2} \mathrm{O}$ & 1.29 & 0.30 & 2.46 & 0.01 \\
$\mathrm{MgO}$ & 4.79 & 10.6 & 1.76 & 0.18 \\
$\mathrm{Al}_{2} \mathrm{O}_{3}$ & 6.00 & 4.75 & 2.68 & 43.87 \\
$\mathrm{SiO}_{2}$ & 20.53 & 13.65 & 18.01 & 51.85 \\
$\mathrm{P}_{2} \mathrm{O}_{5}$ & - & 0.30 & 6.45 & - \\
$\mathrm{SO}_{3}$ & 2.00 & - & 1.82 & - \\
$\mathrm{CaO}$ & 61.89 & 68.57 & 4.86 & 0.20 \\
$\mathrm{TiO}_{2}$ & - & 0.002 & 35.95 & - \\
$\mathrm{Fe}_{2} \mathrm{O}_{3}$ & 3.00 & - & 22.52 & 0.99 \\
$\mathrm{ZnO}$ & - & - & 1.93 & - \\
$\mathrm{K}_{2} \mathrm{O}$ & 0.50 & 0.33 & 0.46 & 0.12 \\
$\mathrm{MnO}$ & $-*$ & 0.04 & 0.12 & - \\
$\mathrm{Cl}$ & - & - & 0.55 & - \\
$\mathrm{Cr}_{2} \mathrm{O}_{3}$ & - & - & 0.08 & - \\
$\mathrm{NiO}$ & - & - & 0.04 & - \\
$\mathrm{CuO}$ & - & - & 0.04 & - \\
\hline
\end{tabular}

*- means trace of element

Phenols and chlorophenols are one of the serious pollutants in effluent industrials. Therefore, phenolic, polychlorophenols, and volatile organic compounds (VOC) for PWS and ash were measured using GC-MS instrument (Agilent Technology GC 7890, Mass Model 5975N). Concentrations of phenolic and VOC compounds for PWS $(<0.002$ ppm) and ash (Table 2) were below the maximum concentration for toxicity characteristic described in EPA | 3 | | standard (EPA Method |3 | |, 2003).

Composite manufacturing

PWS, ash, and MK were replaced with PC. Three ash/PC ratios of $0: 1,0.1: 1$, and $0.15: 1$, three MK/ $P C$ ratios of $0: 1,0.1: 1$, and $0.15: 1$, and three PWS/PC ratios of $0: 1,0.06: 1$, and $0.12: 1$ were used to produce composites. Water/PC ratio was considered as 0.7:I and control composites contained PC and bagasse fibers. 
TABLE 2 Phenolic and volatile organic compounds of petrochemical ash.

\begin{tabular}{|c|c|c|c|c|c|}
\hline Compound & $\begin{array}{l}\text { Concentration } \\
\text { (ppm) }\end{array}$ & Compound & $\begin{array}{c}\text { Concentration } \\
(\mathrm{ppm})\end{array}$ & Compound & $\begin{array}{c}\text { Concentration } \\
(\mathrm{ppm})\end{array}$ \\
\hline Benzene & $<0.01$ & Hexachlorobutadiene & $<0.01$ & epoxyheptachlor & $<0.000$ I \\
\hline Toluene & $<0.01$ & Hexachloroethane & $<0.01$ & D.D.E & $<0.000$ \\
\hline Ethylbenzene & $<0.01$ & 2,4,6-trichloro phenol & $<0.01$ & dieldrin & $<0.0001$ \\
\hline p-Xylene & $<0.01$ & 2,4,5-trichloro phenol & $<0.01$ & D.D.D & $<0.0001$ \\
\hline Styrene & $<0.01$ & nitro benzene & $<0.01$ & Endrin aldhyde & $<0.000$ \\
\hline o-Xylene & $<0.01$ & methyl ethyl ketone & $<0.01$ & Endrin ketone & $<0.0001$ \\
\hline Carbon tetra chloride & $<0.01$ & pyridine & $<0.01$ & Metoxy chlor & $<0.0001$ \\
\hline Chloroform & $<0.01$ & Tetrachloroethylene & $<0.01$ & Endrin & $<0.000$ \\
\hline O-cresol & $<0.005$ & Trichloroethylene & $<0.01$ & Endosulfan & $<0.0001$ \\
\hline m-cresol & $<0.005$ & vinyl chloride & $<0.01$ & Methyl chlor & $<0.000$ \\
\hline p-cresol & $<0.005$ & 2,4-dinitro toluene & $<0.01$ & Chlordane & $<0.0001$ \\
\hline Monochlorobenzene & $<0.01$ & alpha-lindane & $<0.0001$ & Toxaphene & $<0.0001$ \\
\hline I,2-dichloro ethane & $<0.01$ & lindane & $<0.0001$ & I,4- dichloroben-zene & $<0.01$ \\
\hline Heptachlore & $<0.0001$ & I, I-dichloroethane & $<0.01$ & Aldrine & $<0.0001$ \\
\hline
\end{tabular}

To manufacture the composites, superplasticizer was dissolved in water and added to the composition. The composite manufacturing method was according to the previous studies (Khorami; Ganjian, 2011; Mohamkadkazemi et al., 2015). The mortar was mixed using an electric mixer at $1320 \mathrm{rpm}$ for $5 \mathrm{~min}(3 \mathrm{~min}$ mixing with two one-minute pauses). The target density and thickness of composites were $1.2 \mathrm{~g} . \mathrm{cm}^{-3}$ and 12 $\mathrm{mm}$, respectively. The mixture was uniformly poured and distributed on a metal plate inside a frame-like mold (I00× 250× $40 \mathrm{~mm} 3)$; another plate placed on the top of the mat. Two sides of the mat were covered with cellophane to prevent sticking. Thereafter, the mat was cold-pressed under a constant weight for 24h for primary curing to occur. Then, the composite was released from the mold and conditioned at $95 \%$ relative humidity $(\mathrm{RH})$ at room temperature $\left(20 \pm 1{ }^{\circ} \mathrm{C}\right)$. The cured composites were then conditioned at $65 \pm 2 \% \mathrm{RH}$ and $20 \pm 11^{\circ} \mathrm{C}$ for two weeks. Conditioning of composites is necessary due to the moisture uniformity and equilibrium.

Mechanical and physical properties

Measurement of mechanical properties was carried out according to DIN 68763. Modulus of rupture (MOR), modulus of elasticity (MOE), fracture toughness (FT); which is defined as the energy absorbed during the flexural test divided by the cross-sectional area of the specimen (Tonoli et al., 2009), internal bonding strength (IB) which was calculated as shear strength parallel to the surface, and water absorption after 24h immersion in water (WA24). Four replicates were considered for each combination.
Analysis of variance (ANOVA) was used for statistical analysis of the data. Duncan multiple range tests (DMRT) was used to group the averages. The experiment was arranged as a $3 \times 3 \times 3$ factorial in a completely randomized design.

X-ray diffraction $(X R D)$ analysis

$X R D$ patterns were collected in order to identify the main peaks and phases on X'Pert pro-MPD (multi-purpose diffractometer, Model PW3040/60) with CuKa radiation generation at a temperature of $25^{\circ} \mathrm{C}$, resolution of $0.001^{\circ}$. Diffraction intensities were measured between $2 \theta$ of $4-60^{\circ}$ at $40 \mathrm{kV}$ and $30 \mathrm{~mA}$. Before carrying out XRD analysis, fiber-cement samples were ground using a planetary ball mill (Fritsch, Pulverisette 5) below $75 \mu \mathrm{m}$.

Toxicity characteristic leaching procedure

The use of ash that exposed to weathering in practice requires a study of their potential toxicity. To study the potential toxicity of ash, the test recommended by USA EPA (2003) was applied. The concentration of heavy metals was obtained using inductively coupled plasma optical emission spectrometry (ICP-OES), Liberty- RL.

\section{RESULTS AND DISCUSSION}

Effects of PWS, ash, and MK on mechanical properties of FCCs are represented in Figures 2 to 5 . According to the obtained results, MOR, MOE, and FT of composites were increased significantly with the addition of PWS. Composites produced with 6\% PWS content showed superior mechanical properties. PWS contains the suitable amount of fibers 


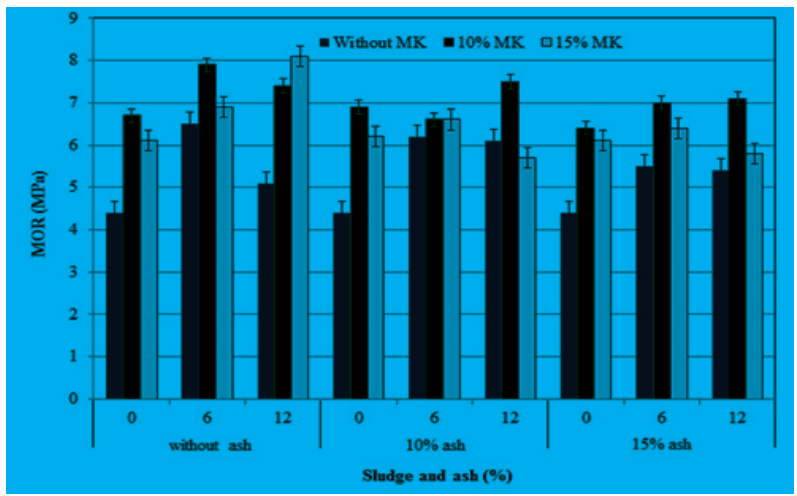

FIGURE 2 Effect of papermaking waste sludge, ash and metakaolin on modulus of rupture (MOR) of fiber-cement composites.

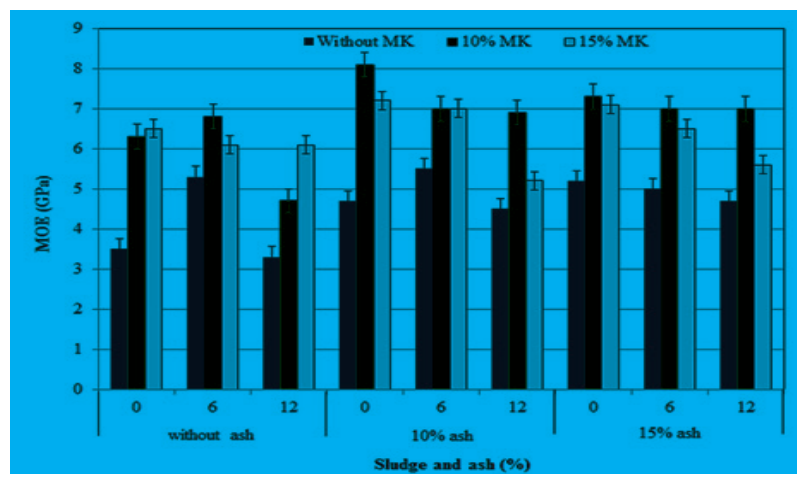

FIGURE 3 Effect of papermaking waste sludge, ash and metakaolin on modulus of elasticity (MOE) of fiber-cement composites.

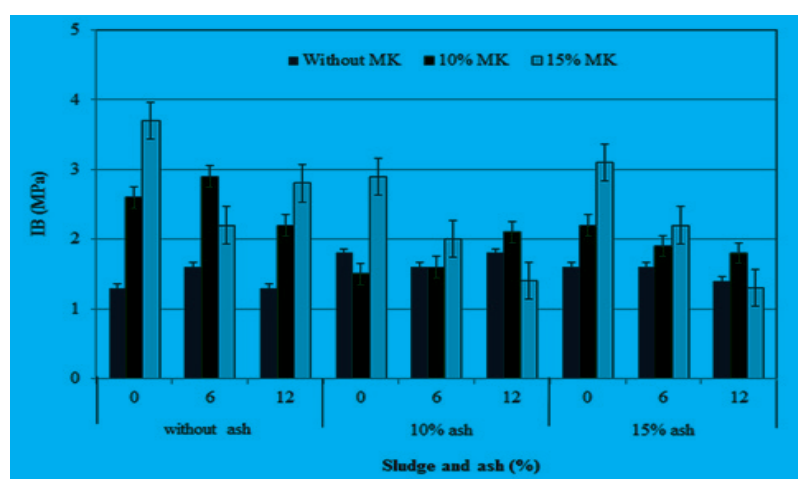

FIGURE 4 Effect of papermaking waste sludge, ash and metakaolin on internal bonding (IB) of fiber-cement composites.

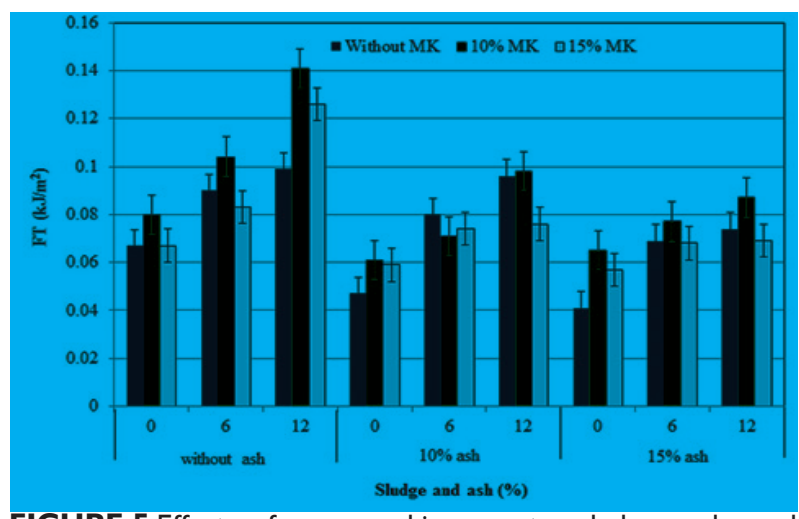

FIGURE 5 Effect of papermaking waste sludge, ash and metakaolin on fracture toughness (FT) of fiber-cement composites.
(50.38\%) and has incremented mechanical properties especially FT; since absorbed energy was increased and more fibers are pulled out from the matrix. In fact, the fibers bridge the matrix cracks and transfer the loads, allowing a distributed microcrack system to develop. It was reported that sludge content of 10\% or more delayed the setting time and reduced mechanical properties of concrete significantly (Johnson et al., 20/4). Nevertheless, FCC containing $12 \%$ PWS have indicated higher FT compared with other combinations.

IB strength of composites was decreased with increasing PWS. Increasing PWS in cement matrix increased fiber to fiber binding, decreased binding fiber to cement, and caused agglomeration within the cement matrix. Broken pieces of bending specimens confirmed non-uniform distribution of PWS fibers in the matrix. This could result in the reduction of fiber-cement interfacial adhesion and hence decreased IB strength. This reduction was highlighted when $12 \%$ PWS and 15\% ash were combined in the mixture. Martínez-García et al. showed that products with 5\% sludge content revealed suitable mechanical properties (MartínezGarcía et al.,2012). When the percentage of paper mill sludge in the concrete increased, mechanical properties decreased. It can be deduced from increasing voids content with increasing PWS. A high correlation was observed between density and strength of the concrete containing paper mill sludge (Nazar et al., 20 I4).

Using ash up to $15 \%$ in composite manufacturing increased MOE of composites while IB and FT were decreased. Petrochemical Ash has a low $\mathrm{CaO}$ content, a material which helps to improve mechanical properties; therefore, some engineering properties were decreased because of difficulties in relation to setting time and adhesion. However, FCC containing petrochemical ash showed acceptable strength levels. It was reported that waste sludge with low destructive components has a low environmental impact (Silva et al., 2007).

Replacing MK with PC has enhanced mechanical properties of composites. FCCs with 10\% MK revealed the highest $\mathrm{MOR}, \mathrm{MOE}$, and $\mathrm{FT}$; however, maximum IB belonged to composites with I5\% MK (Figure 4). Improving mechanical properties of cement-based materials with the addition of MK at various substitution levels was proved. Zhang and Malhotra reported that an addition of $10 \%$ MK increased MOE by $8 \%$ in concrete (Zhang; Malhotra, 1995). Many studies have shown that the initial and final setting times of the cement incorporating 10\% MK were shorter than those of PC (Li; Ding, 2003). It was stated that alkali-silica reaction could be mitigated and compressive and bending strengths enhanced by $10-15 \%$ replacement of cement by MK (El-Din et al., 20 I7; Aquino et al., 200I; Courard et al., 2003; Poon et al., 200I; Ramlochan et al., 2000). 
XRD patterns of FCCs are illustrated in Figure 6. According to the phase identification, peaks located at $2 \theta=18^{\circ}$, $32.1^{\circ}, 34^{\circ}, 47^{\circ}, 50.7^{\circ}, 54.32^{\circ}$ and $56.28^{\circ}(\mathrm{d}(\AA)=4.93,2.78$, $2.63,1.92,1.8,1.69)$ corresponded to portlandite $(\mathrm{CH})$, peaks at $2 \theta=26.5,28^{\circ}, 29.4^{\circ}, 32^{\circ}, 34^{\circ}, 41^{\circ}$ and $50^{\circ}$ corresponded to $\mathrm{CSH}$. Also, peaks at $2 \theta=32^{\circ}, 34^{\circ}, 41^{\circ}, 54^{\circ}$ and $2 \theta=47^{\circ}$, $54^{\circ}$ were attributed to larnite $\left(\beta-\mathrm{C}_{2} \mathrm{~S}\right)$ and calcite $\left(\mathrm{CaCO}_{3}\right)$, respectively. Ettringite, $\left(\mathrm{Ca}_{6}\left[\mathrm{Al}(\mathrm{OH})_{6}\right]_{2}\left(\mathrm{SO}_{4}\right)_{3} \cdot 26 \mathrm{H}_{2} \mathrm{O}\right)$, can be identified at $2 \theta=8.7^{\circ}, 18^{\circ}, 29.4^{\circ}, 32^{\circ}$ and $34^{\circ}$. There were some overlapped peaks in XRD spectral profiles. As can be observed in Figure 6, the main $\mathrm{CH}$ peaks $\left(2 \theta=18^{\circ}\right.$, $32.1^{\circ}$, and $47^{\circ}$ ) in control composites are the highest among other compositions. PWS6-al0-MKIO Composites had the lowest $\mathrm{CH}$ peaks and the highest $\mathrm{CSH}$ and ettringite peaks. Interestingly, this is caused by the reaction of $\mathrm{CH}$ with $\mathrm{MK}$, ash, and PWS which produced CSH responsible for the strength of composites. However, the pozzolanic activity of MK was higher than the rest. XRD results were in accordance with mechanical properties of composites where optimum amounts of components were used. With ternary binder made of CFBC fly ash, conventional fly ash, and calcium hydroxide, proportions of $\mathrm{C}-\mathrm{S}-\mathrm{H}$ and ettringite in the system were grown and compressive strength enhanced (Hlaváček et al., 20 18 ).

Figure 7 shows water absorption of FCCs after $24 \mathrm{~h}$ immersion. WA24 was increased with replacing PWS, ash, and MK. All materials are hydrophilic and intended to absorb

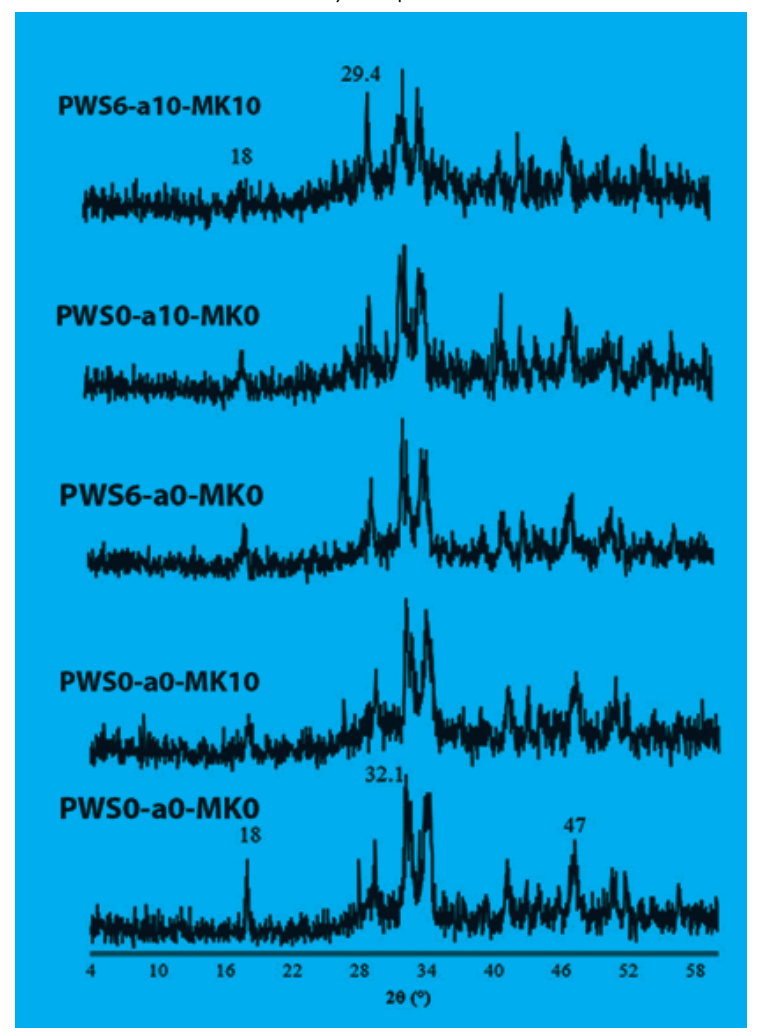

FIGURE 6 X-ray diffractograms of fiber-cement composites. water. MK contains actively amorphous silicon dioxide and aluminum oxide; they can react with hydrates of cement to form $\mathrm{CSH}$ gel and Ettringite. Hence, this process reduced the setting time and increased the water absorption (Li; Ding, 2003). It was confirmed that water absorption of concrete mixtures increased with the increase of MK content (Khatib; clay, 2004; Razak et al., 2004). Cement mixtures containing MK revealed a greater total porosity than the PC pastes (Siddique; Klaus, 2009). PWS is composed of many fibrous materials and enhanced water absorption capacity of composites. Also, ash and PWS contents increased, water absorption increased and density of composites diminished (Yan, 20II). The density of FCCs varied from 1.12 to $1.56 \mathrm{~g} . \mathrm{cm}^{-3}$, represented in Figure 8. Dropping density of composites has proved that voids are developed throughout the matrix with increasing PWS, ash, and MK; accordingly, WA was grown. The least WA was related to FCC containing I0\% MK with no PWS and ash.

To evaluate the toxicity of ash and produced FCC (PWS6-al0-MKIO), heavy metals were measured and compared to the EPA 131 | standard. Table 3 shows the concentration of heavy metals for materials.

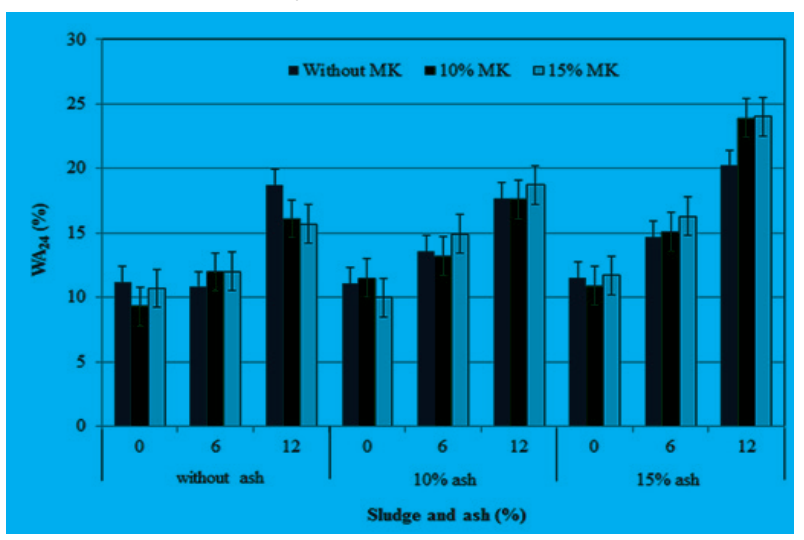

FIGURE 7 Effect of papermaking waste sludge, ash and metakaolin on water absorption (WA24) of fibercement composites.

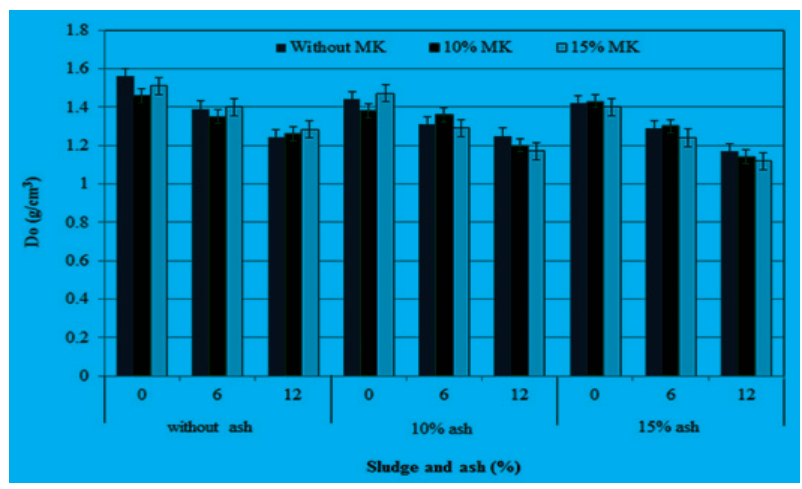

FIGURE 8 Effect of papermaking waste sludge, ash and metakaolin on density of fiber-cement composites. 
TABLE 3 Concentration of heavy metals for petrochemical ash and fiber-cement composite powder compared with permissible levels according to EPA I 3 II standard.

\begin{tabular}{ccccccccccccc}
\hline $\begin{array}{c}\text { Heavy metals } \\
\text { concentration (ppm) }\end{array}$ & $\mathrm{Ag}$ & $\mathrm{As}$ & $\mathrm{Cd}$ & $\mathrm{Hg}$ & $\mathrm{Pb}$ & $\mathrm{Se}$ & $\mathrm{Cr}$ & $\mathrm{Cu}$ & $\mathrm{Mn}$ & $\mathrm{Ni}$ & $\mathrm{Zn}$ \\
\hline Ash & $<0.02$ & $<0.05$ & $<0.02$ & $<0.05$ & $<0.05$ & $<0.05$ & $<0.05$ & 0.73 & 7.89 & 0.68 & 221.07 \\
FCC powder & $<0.02$ & $<0.05$ & $<0.02$ & $<0.05$ & $<0.05$ & $<0.05$ & 0.23 & $<0.05$ & 0.06 & $<0.05$ & 0.1 \\
EPA 131। & 5 & 5 & । & 0.2 & 5 & । & 5 & - & - & - & -* \\
\hline *-means no certain standard limit & & & & & & & & & &
\end{tabular}

As a new interesting result, concentrations of both ash and FCC were lower than permissible values determined by EPA I 3 I I. There is no limit for copper (Cu) and zinc ( $\mathrm{Zn})$ in EPA |31।; however, their concentrations were lower than values reported in the literature (Fernandez Pereira et al., 2007; Galiano et al., 201 I; Ettler et al., 2005). Noticeably, the concentration of all heavy metals in elutes for FCC was significantly decreased compared with ash. It can be attributed to the proper solidification and encapsulation of ash within the cementitious matrix. These results are in accordance with XRD pattern; as PWS6-alO-MKIO Composites had the lowest $\mathrm{CH}$ and the highest $\mathrm{CSH}$ peaks. Increasing $\mathrm{pH}$ value increases the solubility of heavy metals (Aranda, 2008). Combination of MK and PWS in cement matrix reduced the $\mathrm{CH}$ via pozzolanic reactions. Therefore, $\mathrm{pH}$ of elutes was decreased and stabilization and solidification of heavy metals occurred. In addition, Iron oxide (22.52\%) and Silicon dioxide (18.01\%) have a positive effect on anion and metal immobilization in the solidified waste samples, because they act as sorbents, which favor surface complexation and precipitation of anions and metals on their surface (Karamalidis et al., 2010). As can be observed in Table 3 , the concentration of chromium ( $\mathrm{Cr}$ ) was increased in FCC powder $(0.23 \mathrm{ppm})$ compared with neat ash $(<0.05 \mathrm{ppm})$. Nevertheless, it was lower than the permissible standard value (5 ppm). Cr may become incorporated and encapsulated into the nanoporous $\mathrm{CSH}$ gel. Thus, the formation of $\mathrm{CSH}$ with the pozzolanic reaction of FCC materials resulted in increasing the concentration of $\mathrm{Cr}$ to some extent (Aranda, 2008).

\section{CONCLUSION}

The use of industrial waste materials such as PWS and petrochemical ash, and also MK, as an active pozzolanic material, in cement-based composites has gained considerable importance due to the requirements of environmental protection, economic consideration, and supportable construction materials. According to the obtained results of this study, conclusions are as follows:

- MOR, MOE, and FT of composites were increased significantly with the addition of PWS. Composites produced with 6\% PWS content showed superior average mechanical properties. The decreasing effect of PWS content on IB strength can be explained by the reduced bonding ability of fibers to cement with increasing PWS content in the mixture.

- Petrochemical ash is composed of impurities which reduced adhesion to cement; therefore, some engineering properties were decreased with increasing ash content up to 15\%. However, FCC showed acceptable strength levels.

- FCCs incorporating 10\% MK indicated highest $\mathrm{MOR}, \mathrm{MOE}$, and $\mathrm{FT}$; while maximum IB belonged to composites containing I5\% MK.

- Increasing water absorption and reducing the density of composites were observed with the replacement of PWS, ash, and MK with PC.

- According to XRD analysis, $\mathrm{CH}$ peaks was disappeared approximately and $\mathrm{CSH}$ and Ettringite peaks were intensified with the addition of MK, ash, and PWS. This is caused by the reaction of $\mathrm{CH}$ with $\mathrm{MK}$, ash, and PWS which produced $\mathrm{CSH}$ responsible for the strength of composites.

- According to the obtained results, FCC manufactured with 6\% PWS, 10\% ash, and 10\% MK is considered as the optimum combination. Overall, this study indicated the possibility of reusing PWS and petrochemical ash as well as replacement of MK in producing of lightweight FCC with acceptable properties for construction applications.

- It was found that concentrations of heavy metals in both ash and FCC were lower than permissible values determined by EPA $131 \mathrm{l}$. It can be attributed to the proper solidification and encapsulation of ash within the cementitious matrix. Combination of MK and PWS in cement matrix reduced the $\mathrm{CH}$ via pozzolanic reactions. Therefore, successful stabilization and solidification of heavy metals will occur with no environmental concerns.

\section{ACKNOWLEDGEMENT}

This work was supported by the grant from credit research of Shahid Beheshti University G.C. The contract number is 600/19. 


\section{REFERENCES}

ABDEL-KADER, A.H.; DARWEESH, H.H. Setting and hardening of agro-cement composites. Bioresources, v. 5, p. 43-54, 2010.

ANDREOLA, F.; BARBIERI, L.; LANCELLOTTI, I.; POZZI, P. Recycling industrial waste in brick manufacture. Journal of Material Construction Part I, v. 55, p. 5-16, 2005.

AQUINO, W.; LANGE, D.A.; OLEK, J. The influence of metakaolin and silica fume on the chemistry of alkali-silica reaction products. Cement and Concrete Composites, v. 23 , p. $485-493,200$ I.

ARANDA, C. Leaching Test Comparison for Solidified and Stabilized Contaminated Sediments: Assessment of Selected Inorganic Contaminants. 2008. 99 p. MSc Thesis. University of Oslo, Oslo, Norway.

BUTLER, L.G.; CARTLEDGE, F.K.; CHALASANI, D.; EATON, H.C.; FREY, F.; TITTLEBAUM, M.E.; YANG, S. Immobilization mechanisms in solidification/stabilization using cement/silicate fixing agents. In 2nd Annual Symposium on Hazardous Waste Research, Baton Rouge, LA, p. 42-6I, 1988.

CASTELLANOS, N.T.; AGREDO, J.T.; de GUTIÉRREZ, R.M. Calcined Clays for Sustainable Concrete, RILEM Book series, Springer, 20I5. p. 26I-268.

CHANG, F.C.; LIN, J.D.; TSAI, C.C.; WANG, K.S. Study on cement mortar and concrete made with sewage sludge ash. Water Science and Technology, v. 62, p. 16891693, 2010.

CHUNG, Y.M.; NAIK, T.R. Concrete with paper industry fibrous residuals: mixture proportioning. $\mathrm{ACl}$ Materials Journal, v. I02, p. 237-234, 2005.

COURARD, L. DARIMONT, A., SCHOUTERDEN, M., FERAUCHE, F., WILLEM, X., DEGEIMBRE, R.: Durability of mortar modified with metakaolin. Cement and Concrete Research, v. 33, p. I473-I479, 2003.

EL-DIN, H.K.; EISA, A.S.; AZIZ, B.H.; IBRAHIM, A. Mechanical performance of high strength concrete made from high volume of Metakaolin and hybrid fibers. Construction and Building Materials, v. I40, p. 203-209, 2017.

EPA METHOD I3II, Toxicity characteristic leaching procedure test method for evaluation of solid wastes, physical and chemical methods, SW846, prepared by environmental protection agency, US, 2003.

ETTLER, V.; MIHALJEVIC, M.; SEBEK, O.; STRNAD, L. Leaching of $A P C$ residues from secondary $\mathrm{Pb}$ metallurgy using single extraction tests: the mineralogical and the geochemical approach. Journal of Hazardous Materials, v. I2I, p. 149-157, 2005.
FERNANDEZ PEREIRA, C.; LUNA GALIANO, Y.; RODRIGUEZ-PINERO, M.A.; VALE PARAPAR, J. Long and short-term performance of a stabilized/solidified electric arc furnace dust. Journal of Hazardous Materials, v. I48, p. 70|-707, 2007.

FURLANI, E.; TONELLO, G.; MASCHIO, S.; ANEGGI, E.; MINICHELLI, D.; BRUCKNER, S.; LUCCHINI, E. Sintering and characterization of ceramics containing paper sludge, glass cullet and different types of clayey materials. Ceramics International, v. 37, p. I293-1299, 201 I.

GALIANO, Y.L.; PEREIRA, C.F.; VALE, J. Stabilization/ solidification of a municipal solid waste incineration residue using fly ash-based geopolymers. Journal of Hazardous Materials, v. I85, p. 373-38I, 2011.

GENAZZINI, C.; GIACCIO, G.; RONCO, A.; ZERBINO, R. Cement-based materials as containment systems for ash from hospital waste incineration. Waste management, v. 25, p. 649-654, 2005.

GENAZZINI, C.; ZERBINO, R.; RONCO, A.; BATIC, O.; GIACCIO, G. Hospital waste ashes in Portland cement mortars. Cement and Concrete Research, v. 33, p. 1643-1650, 2003.

HLAVÁČEK, P., ŠULC, R., ŠMILAUER, V., RÖßLER, C., SNOP, R. Ternary binder made of CFBC fly ash, conventional fly ash, and calcium hydroxide: Phase and strength evolution. Cement and Concrete Composites, v. 90, p. 100-107, 2018.

JIDRADA, P., SUA-IAM, G., CHATVEERA B., ET AL. Recycling of combined coal-biomass ash from electric power plant waste as a cementitious material: characteristics and improvement. Journal of Materials Cycles and Waste Management, v. 18, p. 527-540, 2016.

JOHNSON, O.A.; NAPIAH, M.; KAMARUDDIN, I. Potential uses of Waste Sludge in Construction Industry, A Review. Research Journal Applied Science Engineering Technology, v. 8, p. 565-570, 2014.

KARAMALIDIS, A.K.; PSYCHARIS, V.; NICOLIS, I.; PAVLIDOU, E.; BENAZETH, S.; VOUDRIAS, E.A. Characterization of stabilized/solidified refinery oily sludge and incinerated refinery sludge with cement using XRD, SEM and EXAFS. Journal of Environmental Sciences, Health A. v. 43, p. II44-II56, 2010.

KHATIB, J.M.; CLAY, R.M. Absorption characteristics of metakaolin concrete. Cement and Concrete Research, v. 34, p. 19-29, 2004.

KHORAMI, M.; GANJIAN, E. Comparing flexural behavior of fiber-cement composites reinforced bagasse, wheat and eucalyptus. Construction and Building Materials, v. 25, p. 366I-3667, 201 I.

LI, Z.; DING, Z. Property improvement of Portland cement by incorporating with metakaolin and slag. Cement and Concrete Research, v. 33, p. 579-584, 2003. 
LOU, R.; WU, S.; LV, G.; YANG, Q. Energy and resource utilization of deinking sludge pyrolysis. Applied Energy, v. 90 , p. 46-50, 2011.

LOVE, C.A.; RICHARDSON, I.G.; BROUGH, A.R. Composition and structure of C-S-H in white portland cement-20\% metakaolin pastes hydrated at $25^{\circ} \mathrm{C}$. Cement and Concrete Research, v. 37, p. 109-II7, 2007.

MARTÍNEZ-GARCÍA, C.; ELICHE-QUESADA, D.; PÉREZVILLAREJO, L.; IGLESIAS-GODINO, F..; CORPAS-IGLESIAS, F.A. Sludge valorization from wastewater treatment plant to its application on the ceramic industry. Journal of Environmental Engineering, v. 95, p. 5343-5348, 2012.

MENHOSH, A.A.; WANG, Y.; WANG, Y. The Mechanical Properties of the Concrete Using Metakaolin Additive and Polymer Admixture. Journal of Engineering, v. 2016, p. I-6, 2016.

MODOLO, R.; FERREIRA, V. M.; MACHADO, L.M.; RODROGUES, M.; COELHO, I. Construction material as a waste management solution for cellulose sludge. Waste Management, v. 3I, p. 370-377, 201 I.

MOHAMMADKAZEMI, F.; DOOSTHOSEINI, K.; GANJIAN, E.; AZIN, M. Manufacturing of bacterial nano-cellulose reinforced fiber-cement composites. Construction and Building Materials, v. I0I, n. I, p. 958-964, 2015.

MOHR, B.J.; NANKO, H.; KURTIS, KE. Durability of kraft pulp fiber-cement composites to wet/dry cycling. Cement and Concrete Composites, v. 27, p. 435-448, 2005.

MONTE, M.C.; FUENTE, E.; BLANCO, A.; NEGRO, C. Waste management from pulp and paper production in the European Union. Waste management, v. 29, p. 293-308, 2008.

NAZAR, A.M.; ABAS, N.F.; OTHUMAN MYDIN, M.A. Study on the utilization of paper mill sludge as partial cement replacement in concrete MATEC. Web of Conferences, v. 10, p. I-8, 2014.

OCHOA DE ALDE JESUS, A.G. Feasibility of recycling pulp and paper mill sludge in the paper and board industries. Resources, Conservation and Recycling, v. 57, p. 965972, 2008.

POON, C.S.; LAM, L.; KOU, S.C.; WONG, R. Rate of pozzolanic reaction of metakaolin in high-performance cement pastes. Cement and Concrete Research, v. 3I, p. I30I-I306, $200 \mid$.

PROTÁSIO, T., JUNIOR, M. G., MIRMEHDI, S., TRUGILHO, P. F., NAPOLI, A., KNOVACK, K. M. Combustion of biomass and charcoal made from babassu nutshell. Cerne. v. 23, p. I-10, 2017.

QIAN, J.; SHU, X.; DONG, Q.; LING, J.; HUANG, B. Laboratory characterization of controlled low-strength materials. Materials and Design, v. 65, p. 806-8I3, 2015.
RAJOR, A.; XAXA, M.; MEHTA, R. Kunal. An overview on characterization, utilization and leachate analysis of biomedical waste incinerator ash. Journal of Environmental Management, v. I08, p. 36-4I, 2012.

RAMLOCHAN, T.; THOMAS, M.; GRUBER, K.A. The effect of metakaolin on alkali-silica reaction in concrete. Cement and Concrete Research, v. 30, p. 339-344, 2000.

RAZAK, H.A.; CHAI, H.K.; WONG, H.S. Near surface characteristics of concrete containing supplementary cementing materials. Cement and Concrete composites, v. 26, p. $883-889,2004$.

SABIR, B.B.; WILD, S.; BAI, J. Metakaolin and calcined clays as pozzolans for concrete: a review. Cement and Concrete Composites, v. 23, p. 44I-454, 200 I.

SHEKARCHI, M.; BONAKDAR, A.; BAKHSHI, M.; MIRDAMADI, A.; MOBASHER, B. Transport properties in metakaolin blended concrete. Construction and Building Materials, v. 24, p. 2217-2223, 2010

SIDDIQUE, R.; KLAUS, J. Influence of metakaolin on the properties of mortar and concrete: A review. Applied Clay Science, v. 43, p. 392-400, 2009.

SILVA, M.; MATER, L.; SOUZA-SIERRA, M.; CORR^EA, A.; SPERB, R.; RADETSKI, C. Small hazardous waste generators in developing countries: use of stabilization/ solidification process as an economic tool for metal wastewater treatment and appropriate sludge disposal. Journal of Hazardous Materials, v. I47, p. 986-90, 2007.

SPENCE, R., SHI, C. Stabilization and Solidification of Hazardous, Radioactive, and Mixed Wastes. CRC Press, 2004. 392p.

TAY, J.H. Sludge ash as filler for Portland cement concrete. Journal of Environmental Engineering, ASCE II3, p. 278-283, 1987.

TONOLI, G.H.D.; RODRIGUES FILHO, U.P.; SAVASTANO, Jr.H.; BRAS, J.; BELGACEM, M.N.; ROCCO LAHR, F.A. Cellulose modified fibers in cement based composites. Composites Part A, v. 40, p. 2046-2053, 2009.

WU, H., HUANG, B., HUANG, X., YIN, J. Utilization of solid wastes/byproducts from paper mills in Controlled Low Strength Material (CLSM). Construction and Building Materials, v. II8, p. I55-163, 2016.

YAN, S.; SAGOE-CRENTSILA, K.; SHAPIRO, G. Reuse of deinking sludge from wastepaper recycling in cement mortar products. Journal of Environmental Management, v. 92, p. 2085-2090, 201 I.

ZHANG, M.H.; MALHOTRA, V.M. Characteristics of a thermally activated aluminosilicate pozzolanic material and its use in concrete. Cement and Concrete Research, v. 25, p. I7|3-1725, 1995. 